Meta

Journal des traducteurs

Translators' Journal

\title{
The Role and Teaching of Theory in Translator Training Programmes
}

\section{Roda P. Roberts}

Volume 33, numéro 2, juin 1988

L'enseignement de la traduction au Canada - Teaching Translation in Canada

URI : https://id.erudit.org/iderudit/003960ar

DOI : https://doi.org/10.7202/003960ar

Aller au sommaire du numéro

Éditeur(s)

Les Presses de l'Université de Montréal

ISSN

0026-0452 (imprimé)

1492-1421 (numérique)

Découvrir la revue

Citer cet article

Roberts, R. P. (1988). The Role and Teaching of Theory in Translator Training Programmes. Meta, 33(2), 164-173. https://doi.org/10.7202/003960ar d'utilisation que vous pouvez consulter en ligne.

https://apropos.erudit.org/fr/usagers/politique-dutilisation/ 


\title{
THE ROLE AND TEACHING OF THEORY IN TRANSLATOR TRAINING PROGRAMMES
}

RODA P. ROBERTS

University of Ottawa, Ottawa, Ontario

\begin{abstract}
"Theoritical" is an adjective often used pejoratively both by translation students and professional translators when they wish to denigrate translator training programmes. This negative attitude towards "theory" in translation programmes is reflected in the following extract from the proceedings of a round table on the teaching of translation held in 1975:
\end{abstract}

P.H. (Professor) - Monsieur Gervais, à titre d'étudiant qui a déjà fait deux stages, pouvezvous établir une comparaison entre les deux modes de formation? (University translator training programme and on-the-job training or practicum.) Se complètent-ils ou l'un peut-il remplacer l'autre?

G.G. (Student) - L'un ne remplace pas l'autre, mais il est vrai que, comme beaucoup de boursiers du gouvernement fédéral, j'ai appris deux fois plus en six mois de stage qu'en deux années d'étude. Il n'y a pas incompatibilité entre théorie et pratique, mais l'enseignement de l'un est trop déphasé par rapport à la réalité de l'autre.

P.H. (Professor) - Autrement dit, vous n'arrivez pas à établir un rapport entre l'enseignement, disons théorique, qu'on vous donne, bien qu'il nous paraisse pratique, et son application au milieu du travail?

G.G. (Student) - Non. La différence entre la théorie et la pratique est trop grande. ${ }^{1}$

(Meta, 20:1, March 1975, p. 45)

Influenced in large part by comments such as these, translator trainers in Canada have made a valiant effort in the last ten years to make translator training programmes more practical. Programme reforms have resulted in the elimination of many or most theoritical courses and the number of practical translation courses has increased tremendously. This evolution can be clearly seen in the following table, which analyzes the proportion of "theoritical" courses and "practical" courses required by the School of Translators and Interpreters of the University of Ottawa in 1973 and in 1984.

A similar evolution in compulsory courses has taken place in all translation programmes of long standing in Canada, and it definitely marks a change for the better in that translation is a practical operation that can best be learned through practical courses.

However, the pendulum has perhaps swung too far the other way. The muchhated and not necessarily useful lecture courses in Saussure, bilingualism, semantics, etc. of the early 70's have been replaced, to a large extent by what Jean Delisle has termed "séances-bricolage de traduction orale improvisées" and "séances-crucifixion de correction" (Delisle 1979), which are not necessarily more useful in the long run. The original pedagogical philosophy whereby knowledge about language and translation was considered an essential component of translator training has given way to the new 


\begin{tabular}{|c|c|c|c|c|}
\hline & \multicolumn{2}{|c|}{1973} & \multicolumn{2}{|c|}{1984} \\
\hline & Percentage & $\begin{array}{l}\text { No. of } \\
\text { credits }\end{array}$ & Percentage & $\begin{array}{l}\text { No. of } \\
\text { credits }\end{array}$ \\
\hline $\begin{array}{l}\text { Theoretical Courses } \\
\text { (i.e courses in } \\
\text { linguistics, } \\
\text { comparative linguistics, } \\
\text { history and/or theory of } \\
\text { translation) }\end{array}$ & 41,7 & 30 & 18 & 12 \\
\hline $\begin{array}{l}\text { Practical Courses } \\
\text { (i.e. courses in } \\
\text { language, translation, } \\
\text { terminology, } \\
\text { documentation) }\end{array}$ & 58,3 & 42 & 82 & 54 \\
\hline
\end{tabular}

philosophy of practice (and correction) makes perfect. Theory has been pushed aside if not pushed out - into a few courses, the theoritical nature of which is often disguised by titles such as "Text analysis", "Comparative stylistics" or "Comparison of translations". But if purely practical courses have won the day, there is nevertheless dissatisfaction with the approach used in these courses. This is clearly indicated by Jean Delisle, not only in the article cited above, but also in "Plaidoyer en faveur du renouveau de l'enseignement pratique de la traduction professionnelle" (Delisle 1981, 291-296), and by $\mathrm{J}$. Orsoni and $\mathrm{R}$. Larose, l'Enseignement de la traduction et la préparation des iravaux (1979). While the stated reasons for the dissatisfaction may vary (e.g. imposition by the professor of his version as the model, inadequate information provided to students about the texts they are asked to translate, monotony of the translation/ correction method), the general consensus is that something is lacking in practical translation classes. This "something" may be theory - not isolated in a separate course or courses as is the case at the moment, but intimately linked to practice. This seems to correspond with the opinion of Aline Manson-Daoust, who, as a revisor at the Translation Bureau, was one of the participants at the 1975 round table on the teaching of translation :

A.M.D. - Je me permettrai quelques critiques. Il me semble que les professeurs n'ont pas assez de recul par rapport à la traduction qu'ils enseignent; ils n'ont pas vraiment réféchi sur le processus de la traduction et ne peuvent donc l'expliquer aux étudiants. L'étudiant ne comprend pas; il ne retient que les recettes de cuisine. De son côté, le réviseur n'a souvent pas la formation nécessaire pour enseigner autre chose que des recettes. En définitive, tout le monde enseigne des recettes; il n'y a jamais un véritable enseignement théorique. (Meta, 20:1, 1975, p. 47.)

And yet Jean Darbelnet, a pioneer in the teaching of translation in Canada says in a paper entitled "De la conception à l'enseignement de la traduction" : "...je fais peu de cas de la théorisation" (Darbelnet 1984, 272). Why this negative reaction on his part? The problem seems to lie in his conception of theory as something abstract, vague and substantive, at least in the field of translation. However, if we adopt as our definition of translation theory Peter Newmark's idea that it is "the body of knowledge that we have... about the process of translation", which "provides a framework of principles ... for translating texts and criticizing translations, a background for problem-solving" 
(Newmark 1981, 19), Darbelnet would certainly concede that theory has its place in the teaching of translation, for he does believe in moving from the particular to the general, in exacting and presenting principles that can be illustrated by concrete examples (Darbelnet 1984, 272).

If we are then to integrate some theorical reflection into the teaching of translation, we must first derive, from the practice of translation, some basic, general principles. On the basis of my practical experience as a translator and of the numerous works I have read on translation theory, I propose the following eight general principles of translation, which are interconnected and which can, in turn, be broken down into more specific principles.

(1) Translation is an act of communication which allows an original source to communicate a message to intended receptors who do not speak the same language, by means of a translator (Nida, 1964, 1974 ; Pergnier, 1978 ; Roberts, 1981).

(2) Translation is an act of written communication involving two languages whose signs rarely correspond exactly because of their polysemy and the structural servitudes and preferences of each language (Vinay-Darbelnet, 1958 ; Pergnier, 1978).

(3) However, although translation uses language, it is not a purely linguistic operation but an operation dealing with a message; in other words, the translator deals not only with structural meaning but also and primarily with message meaning (Seleskovitch, 1975; Pergnier, 1978 ; Delisle, 1980 ; Pergnier \& Roberts, 1984).

(4) The message meaning of signs is revealed by context and situation - above all, by the communicative situation which consists of four parameters (source, subject, vector, and intended receptor) (Nida, 1974 ; Seleskovitch, 1975 ; Pergnier, 1978 ; Delisle, 1980 ; Roberts, 1981, 1982).

(5) The situational parameters change during the process of translation, which means that equivalence of message is even harder for the translator to achieve (Nida, 1974 ; Pergnier, 1978 ; Roberts, 1981).

(6) However, each message has a primary function and each primary function focuses on one situational parameter more than on others, and if the translator maintains that primary function by focusing more particularly on the parameter most important to it, he will manage, despite the change in parameters, to establish equivalence (Nida, 1974 ; Pergnier, 1978 ; Newmark, 1981 ; Roberts, 1981).

(7) Because of the lack of identity between languages, the equivalence thus established will not be word equivalence but message equivalence (Vinay-Darbelnet, 1958 ; Nida, 1974 ; Seleskovitch, 1975 ; Pergnier, 1978 ; Delisle, 1980 ; Pergnier \& Roberts, 1984).

(8) Equivalence can be said to have been established when all the ideas in a text have been conveyed in the manner most appropriate in light of the function of the message involved (Vinay-Darbelnet, 1958; Nida, 1974).

(Adapted from Roberts 1984, 8)

These general principles which are intended to help translation students make choices and decisions when faced with a text to translate, should be presented to them, not in the form of lectures "on" translation, but as an integral part of practical courses in translation. In other words, the professor should introduce them as and when necessary, on the basis of specific problems presented by specific texts. While this means that the principles would not be exposed in the logical order proposed above, the fact that they were deduced naturally from problem passages would help students remember them better than would a mere "theoritical" presentation of them, however coherent it may be. 
The only principle that needs to be introduced from the start is the first one, which makes clear the primary function of translation as an act of communication by means of language. Even this can be communicated in a simple and practical way from the first day of classes. The professor can distribute to the students a short text to be translated - for instance, a letter, such as the following :

École de traducteurs et d'interprètes Université d'Ottawa

5 , rue Hastey

Ottawa, Ontario

K1N 6N5

le 11 décembre 1984

Mademoiselle Marie Paul

1336, avenue " $Z$ "

Ottawa, Ontario

K1G OB3

Mademoiselle,

J'ai le plaisir de vous faire parvenir ci-joint le nouvel annuaire de l'École, mis à jour pour l'année universitaire 1985-1986. Vous y trouverez toutes les dates-limites importantes en ce qui concerne les formalités d'admission de l'École.

Veuillez agréer, Mademoiselle, l'expression de mes meilleurs sentiments.

Le directeur,

Roda P. Roberts

Pièce jointe

RPR/dl

The advantage of using a letter at this stage is that it represents a tangible act of communication in which both the source and the intended receptor are clearly identified. After distributing the letter, the professor can ask the students a few rapid questions to help them focus on analysis of the source text : who has written the text ? to whom is it written? what is the reason for the text ? In this way, without expounding on the importance of the participants in the communicative act or its purpose, he makes the students aware of factors that must normally be determined prior to translation. After this "introduction", he can ask the students to translate the letter into English, using dictionaries if they wish.

The completed translation may then be passed on to another student who, playing the role of the intended receptor - in this case Marie Paul - must respond to the same questions as above, but on the basis of the information presented in the translation before him. Additional questions such as "In what capacity has the writer written this letter ?" could help to ensure that details such as the title and address are not forgotten. By means of such questions, one can stress the importance of transmitting faithfully and integrally in translation the entire content of a source text.

But how does one grasp the content? Words taken individually can be misleading, as various possible student "translations" of "annuaire" in this text will reveal. The 
professor should explain that "annuaire", like many, if not most, words, is polysemous and can theoretically be rendered by "yearbook", "annual", "directory", etc. (cf. "the School") and the communicative situation (the Director of the School sending information in a potential student) helps determine the precise meaning of "annuaire" in this text, and that in an academic situation such as this, "annuaire" is normally rendered by "calendar".

There is yet another point to be made : that a message involves not only content but also form. Form itself covers both the use of correct and idiomatic linguistic forms and the choice of forms in terms of the intended reader and the type of text. While it may not be possible to get both these aspects across to the student in one class session, the professor can certainly bring out the importance of the former, by having each student pick out in the translation in front of him all linguistic forms that he finds "bizarre" and then by analysing some of them with the students. For instance, a number of students will, no doubt, have translated "J'ai le plaisir de vous faire parvenir le nouvel annuaire de l'École" as "I have the pleasure of sending you..." This is the ideal opportunity to make the distinction between what is correct grammatically and what is both correct and idiomatic : "I have the pleasure of....", while a perfectly correct structure, is not idiomatic (i.e. it does not correspond to the genius, habit or cast of English), while "I am pleased to..." is both correct and idiomatic. Influenced by the much-used bilingual dictionary, Robert and Collins, some students might translate the same expression by "It is with great pleasure that...". This would give the professor the chance to talk about situation and register. The situation which permits the writing of this letter is a request for information by a student applicant, in response to which the Director sends the latest School calendar providing this information. This situation, which is formal and business-oriented, involves two participants who do not know each other. In such a situation the flowery, although correct, expression "It is with great pleasure that..." would be inappropriate at best. Discussion of this version in the way described above would not only bring out the second aspect of form mentioned above (the choice of forms to be made in terms of the intended receptor and the type of text), but it would also introduce the concept of situation affecting the form of a text, which is found in principle 8 .

Study of detailed points and principles can be reviewed at the end of the class by comparing a good translation model such as the following with the source text $\mathrm{p}$.

Such comparison would allow the professor to stress the points of principle brought out previously : (a) Translation is an act of written communication, just like a letter. (Part of general principle 1.) (b) To communicate a message one has to have something to say (purpose and subject of communication) and know to whom one is communicating the message ; in the case of translation, one must also know who the original writer is. (Part of general principles 1 and 4.) (c) Translation involves faithful and complete communication of the content. (Part of general principles 1, 3 and 8.) (d) 


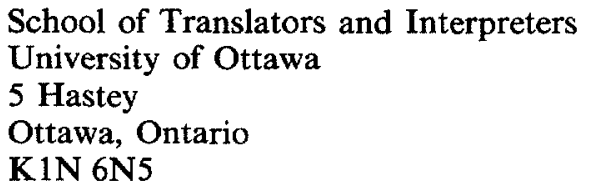

December 11, 1984

Miss Marie Paul

1336 Avenue $Z$

Ottawa, Ontario

$\mathrm{K}_{1 \mathrm{G}_{2} \mathrm{OB} 3}$

Dear Miss Paul,

The School is pleased to send you our new 1985-1986 Calendar, which indicates all pertinent dates and deadlines for admission procedures at the School.

Yours sincerely,

Roda P. Roberts

Director

Encl.

RPR/dl

While words are used to communicate the content of a message, they are often misleading because of their polysemy (cf. annuaire). However, context and situation help determine the specific meaning that a word takes on in a particular instance of use. (Part of general principles 2 and 4.) (e) Reproducing the content faithfully does not mean that one has to reproduce the original word for word (cf. $J$ 'ai le plaisir de...). In fact, this is often not possible. The translator has to present the message correctly and idiomatically in the target language. (Part of general principles 2, 7 and 8.) (f) The communicative situation can influence the choices a translator makes (cf. "calendar"). (Part of general principles 4 and 7.) (g) The translation must communicate the content in the most appropriate manner in terms of the purpose of the message, the intended receptor (cf. "The School is pleased to" vs "I have the great pleasure of"). (Part of general principle 8.)

This list of points of principle, drawn up on the basis of just one introductory text, reveals how each of the general principles can be subdivided into several specific principles. In turn, each of these specific principles can become the objective of specific exercises designed by the teacher to help students assimilate the principle and thus avoid repeating the same type of error endlessly.

For instance, general principle 4 which states that the message meaning of signs is revealed by context and the communicative situation can be broken down into two components, one dealing specifically with context and the other with situation. The role of context in translation can be summed up by two specific principles : (1) context may elucidate problems in comprehension of the source message ; (2) context may determine the choice of words in transfer. These two specific principles underline at least two specific teaching objectives : (1) the student should be able to understand globally the meaning of the source text using context to help elucidate any message meaning problems ; (2) the student should be able to choose the right word in transfer on the basis of context, rather than by sole reliance on bilingual dictionaries. Each of these objectives 
could be attained by a series of exercises such as the following, which have been prepared with the importance of context in understanding of the source text (specific objective 1 above) in mind.

\section{Exercise I}

Each of the following sets of sentences contains a common polysemous word (italicized). Determine the precise meaning that the given word takes on in context, underlining every element in the sentence that provides a contextual clue as to the meaning. Then translate the sentences, paying special attention to the transfer of the contextual meaning of the polysemous word.

I.

1. Le ministre ou le secrétaire d'État présidera la cérémonie.

2. Un crayon ou une plume sont également bons.

3. Alors que le Québec était dépourvu de charbon ou de pétrole, c'est l'équipement du site hydro-électrique de Shawinigan qui y a attiré à cette époque en Mauricie l'usine de papier, l'aluminerie ou la fabrique de carbure de calcium.

4. Simultanéité révélatrice, et d'ailleurs dans l'ordre des choses, c'est au moment où dans un nouvel élan, le Québec s'efforçait de retrouver au moins partiellement la maîtrise de son destin ou de faire meilleur usage de ses compétences constitutionnelles, que l'État québécois s'est engagé dans une politique d'affirmation et de présence sur le plan international.

II.

1. La Terre tourne autour du Soleil.

2. Il faut creuser un trou dans la terre.

3. Le navire s'éloignait du port, et bientôt on cessa de voir la terre.

4. Il voudrait voir sa terre natale.

5. Il a une terre en Normandie.

\section{Exercise II}

The following sentences contain a word whose meaning depends in large part on the origin of the text. Using the brief bibliographic reference provided, as well as contextual clues, determine the precise meaning of the italicized word in the given sentences. Then translate the sentences, paying special attention to this word.

1. Dans ce même esprit de collaboration, des discussions ont été amorcées, depuis notre dernière conférence, entre Terre-Neuve et le Québec, en vue d'aplanir les difficultés courantes et d'en venir à une entente sur le développement éventuel des ressources hydro-électriques.

\section{Quebec Government Text}

2. ... il n'y a guère que le choix entre un mal certain et un mal éventuel.

André Gide, Si le grain ne meurt

(Roberts 1983, 16-17)

Exercises such as these, advocated for several years now by Delisle $(1980,1984)$ and Roberts $(1982,1983)$, provide the advantage of isolating a specific principle and allowing students to focus on it alone, but in a very special way. While it may be argued by some that exercises such as these are "artificial" in that translation involves facing a multitude of problems all at the same time, it must not be forgotten that, at the learning stage, work on specific problems in light of specific principles, gives the student a better grasp of these problems and the principles which may help to resolve them. In any case, such exercises should be used in addition to, and not instead of, regular weekly translations. They are a most useful way to reinforce points of principle brought up during the 
correction of translations, and in certain cases to prepare students for a new problem they will face in the following week's translation assignment.

The combination of theory and practice through error correction and specific exercises should not be limited to general translation courses either. "Theory" - at least in the light considered in this paper - has a role to play in specialized and technical translation courses as well. The use of context, for instance, would help the student grasp at least globally - the concepts underlying terms found in specialized texts. The use of supplementary documentation to understand the subject matter of a source text is an attempt to grasp the message presented more completely. The intended receptor and the knowledge - or lack of it - take on even more importance in the case of a technical text, given the specialized nature of the information to be transferred. In fact, one could go through each of the general principles presented in this and show that they apply to specialized texts. There is therefore no justification, in my opinion, for eliminating theoritical precepts, or specific exercises to illustrate them (see Annex), from courses dealing with the translation of such texts.

If theory and practice were judiciously combined in each practical translation course as I have indicated above, there would obviously be less need for specifically theoritical courses. The latter could then be reduced to a strict minimum - perhaps only one final-year course, whose primary objective would be to review and enlarge on translation principles already brought out in the practical translation courses. A review of the principles could be done by means of analysis of translations, commented translations or commented revisions. The professor could then present these principles in more detail, in logical order to ensure that students see how, when put together, they present an organized system of concepts which attempts to explain what translation is and how it works. Time permitting, the professor could also cover specific translation problems, such as metaphors or cultural differences, in an attempt to apply the theoritical principles to particularly thorny issues.

Since theoritical reflection would not be limited to a restricted number of so-called theoritical courses if practice and theory were combined in the existing practical courses, students, accustomed to such reflection, would be likely to participate keenly in the final-year theory course. Their input, in the form of examples, comments and criticisms, could transform the conventional theory course from a lecture course into a real seminar. And from the interaction between professor and students at this level could emerge fresh ideas, new guiding principles to further help translators in their choices and decisions.

Choices and decisions - that is what translation involves. There are few pat answers, and problems are many and varied. Even after ten years of translating one cannot claim to have encountered all possible hurdles and found a way to overcome all obstacles. Each new text to be translated has its own set of traps and the solutions are not necessarily the same as those used in a previous translation. While it is important for the translation student to encounter as many translation problems as possible during translator training, by translating regularly and often, it is just as important for him - if not more so - to reflect on these problems and draw general conclusions and principles from them, which will stand him in good stead when the inevitable new problems arise. We, translator trainers in Canada, should borrow Eugene Nida and Charles Taber's idea of the indissociability of theory and practice (1974) and provide our students, not only with skills, but also with the principles required to guide them in their chosen profession. 


\author{
Annex \\ Exercises adapted for specialized translation courses
}

Source text

Il est toujours à conseiller de s'assurer, que l'on soit propriétaire ou locataire, un accident est si vite arrivé. On peut prendre une assurance protégeant ses biens (assurance contre les incendies); une assurance contre les dommages découlant de ses animaux, de ses enfants mineurs (assurance contre la responsabilité civile).

Il existe un type de contrat d'assurances appelé "police des propriétaires occupants". C'est le plus complet : une seule prime protège les biens contre des risques variés (incendie, fuite d'eau, vol, etc.) et inclut la responsabilité civile. S'informer soigneusement auprès de l'agent ou du courtier d'assurances de tout ce qui est assuré et de tout ce qui ne l'est pas, comme les dépendances, le garage, les remises, les arbres, les antennes de télévision, les biens personnels, etc.

S'informer aussi des causes de sinistres contre lesquels on est ou non assuré : fumée, incendie, ouragan, foudre, etc.

Guide du citoyen, Éditeur officiel du Québec,

Québec, 1975, pp. 166-167

Specific principles underlying exercise : (1) Judicious use of context helps understanding of terms. (2) Supplementary documentation helps grasp the message more completely because knowledge of the subject matter is required to grasp the message of specialized texts.

Exercise I

The source text provided (see above) is on the subject of insurance. Read the text carefully and then circle all the terms that belong specifically to the field of insurance. Then underline any elements in the text that may help to explain the concept underlying each term.

\title{
Exercise II
}

Read the text provided (see above). Then look for encyclopaedia articles on insurance, in both French and English, which provide the following information :

1. definition of insurance ;

2. meaning of "prime" ;

3. names in French and English of three types of insurance that one can buy.

\section{Exercise III}

Read the text provided (see above). Then find the following documentation to help you better understand and translate the text :

1. a home insurance policy in French ;

2. any reference work in English on insurance;

3. a bilingual (French/English) dictionary on insurance.

Note

1. Explanations in brackets added for clarification 


\section{BIBLIOGRAPHY}

DARBELNET, J. (1984) : "De la conception à l'enseignement de la traduction", in la Traduction : l'universitaire et le praticien, A. Thomas and J. Flamand (edit.), Ottawa, University of Ottawa Press, pp. 271-275.

DELISLE, J. (1979) : "Une discipline en quête d'une méthode", l'Antenne, vol. X, no 6.

DELISLE, J. (1980) : l'Analyse du discours comme méthode de traduction, Ottawa, University of Ottawa Press.

DELISLE, J. (1984) : l'Analyse du discours comme méthode de traduction - livre du maitre, 2nd ed., Ottawa, University of Ottawa Press.

DELISLE, J. (1984) : "Plaidoyer en faveur du renouveau de l'enseignement pratique de la traduction professionnelle", in la Traduction : l'universitaire et le praticien, A. Thomas and J. Flamand (edit.), Ottawa, University of Ottawa Press, pp. 291-296.

NEWMARK, P. (1981) : Approaches to Translation, Oxford, Pergamon Press.

NIDA, E. (1964) : Toward a Science of Translating, Leiden, Brill.

NIDA, E. (1974) : The Theory and Practice of Translation, Leiden, Brill.

PERGNIER, M. (1978) : les Fondements sociolinguistiques de la traduction, Paris, Honoré Champion.

PERGNIER, M. \& R.P. ROBERTS (1984) : "Quelle théorie sémantique pour la traduction ?", The Tenth LACUS Forum.

ROBERTS, R.P. (1981) : "Translation : An Act of Communication", Bulletin de l'ACLA, Autumn, vol. 3, no 2 , pp. 152-163.

ROBERTS, R.P. (1982) : "Le rôle du contexte et de la situation en traduction", Actes du colloque sur l'enseignement du français et de la traduction en Amérique latine, Buenos Aires : INSP, pp. 180-192.

ROBERTS, R.P. (1982) : "Exercices particuliers prévus pour l'enseignement de la traduction vers la langue seconde", Actes du $2^{e}$ colloque sur l'enseignement du français et de la traduction en Amérique latine, Buenos Aires : INSP, pp. 210-221.

ROBERTS, R.P. (1983) : Teaching Students to Translate into their Second Language : Pitfalls, Problems, Expectations, Exercises, California : TIES.

ORSONI, J. \& R. LAROSE (1979) : "L'enseignement de la traduction et la préparation des travaux", l'Antenne, vol. $\mathrm{X}, \mathrm{n} \times 3$.

SELESKOVITCH, D. (1975) : Langage, langues et mémoire, Paris, Minard.

"Table ronde sur l'enseignement de la traduction" (1975) : Meta, 20:1, pp. 42-57.

VINAY, J.-P. \& J. DARBELNET (1958) : Stylistique comparée du français et de l'anglais, Paris, Didier. 